\title{
Design and Fabrication of Cost Effective Mould Tool
}

\author{
J. Senthil, M. Saravanan, Alby Berchmans, Bipin Wilson, Christin Varghese
}

\begin{abstract}
As one third of the plastics are injection moulded, the detailed study of design and fabrication of cost effective mould becomes inevitable. This work focuses on the elaborate procedure for designing and fabricating a mould tool. Optimal setting up of injection molding process variables plays a very important role in controlling the quality of the injection molded product. We designed and produced cable clamp for various purposes. What makes this product unique from others is that low cost and high productivity. Solid edge Software is used for designing and analysis. Material used for this production is polypropylene. The production rate will be high with low cost.
\end{abstract}

Keywords: Injection molding, Injection molding machine, Polypropylene, Design of the Mold tool, Manufacturing of mold tool.

\section{INTRODUCTION}

Injection molding is one of the most extensively used methods for manufacturing plastics parts. Design and manufacturing of an Injection Molding Tool for a CABLE CLAMP, is the task in this project. This work covers the injection mold designand manufacturing of double impression Injection mold for cable clamp Component and is aimed at a high productivity. A new tool with higher productivity and quality parts are the primary requirements.

Geometric profiles, surface quality, material specification, in-service condition were the first step. Design exercise involves choice of parting surface, allowance for shrinkage, draft, side-core movement, gate location, venting, balancing of the mold and choice of ejection system.

The design of the tool includes the design of core and cavity inserts sub-inserts\& side-core assembly. Design of the Mold Base using the DME standards, which can be done after analyzing the component and using simple calculations like weight of the component, shot weight and clamping force.

\section{DESIGNING PROCEDURE}

\section{A. Component Details}

Component Name : Cable clamp

Plastic Material : Polypropylene

Shrinkage : $0.5 \%$

Application : In the field of electrical wiring to hold the 20 mm pipe.

The injection molding tool for the production of these components is manufactured with the following methodology.

- Concept design.

- Tool design and modeling.

- Tool Materials.

- Tool Fabrication, Assembly \& Tryout.

\section{B. Concept Design}

This section of the work involves the detailed study of the component followed by identification of some important features such astheir dimensions and the respective problems they could cause. This section also involves the selection of the parting surface in the component, concept design of the side core mechanism (Cam Block), Ejection Mechanisms etc.

\section{Modeling - Tool}

"Solid Edge 2010" is the software used for tool modeling . Also includes the 3D model of the tool parts, assembly, drawings etc.

Suitable material is selected depending on the requirements and functions. Manufacturing of Tool is done according to the process planning planned for each part of the tool and the corresponding fits are maintained followed by desired surface finishing and inspection. The blue matching of mating parts is done followed by the final assembling. Finally the tool is loaded in the machine and the part is produced.

\section{Component Design}

Figure 1 and figure 2 shows the component design and detailed design of cable camp

Revised Manuscript Received on December 16, 2019

* Correspondence Author

J.Senthil *, Assoc. Prof., Department of Mechanical Engineering, Aarupadai Veedu Institute of Technology, Vinayaka Mission's Research Foundation, Deemed to be University, Chennai, India.

M.Saravanan, Assistant Professor, Mechanical Department, Aarupadai Veedu of Technology, Vinayaka Mission's Research Foundation, Deemed to be University, Chennai, India.

Alby Berchmans, Bipin Wilson, Christin Varghese, UG Student, Department of Mechanical Engineering, Aarupadai Veedu Institute of Technology, Vinayaka Mission's Research Foundation, Deemed to be University, Chennai, India. 


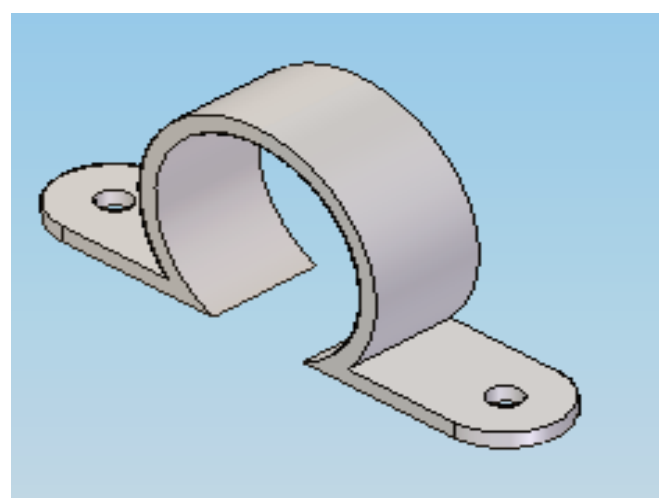

Fig. 1. Component Design
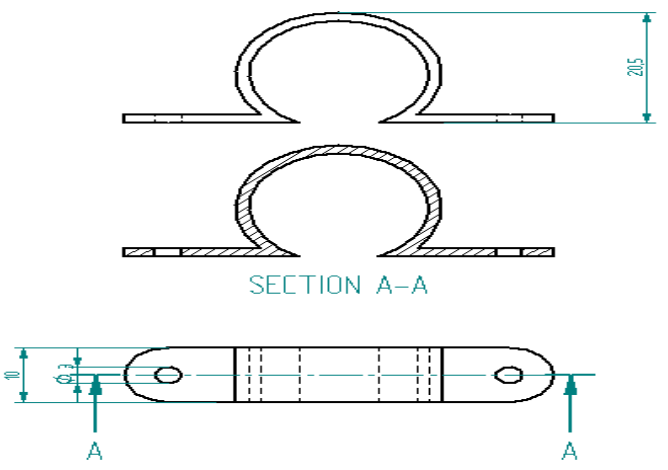

Fig. 2. Detailed design of cable clamp

\section{E. Design of the Mould Tool}

Following are the parameters considered while designing the mould tool

\section{- WEIGHT OF THE COMPONENT}

Weight $=$ (Volume $\mathrm{X}$ Density)

Volume of component $=1.254 \mathrm{~cm} 3$

$\begin{aligned} \text { Density } & =0.913 \mathrm{~g} / \mathrm{cm} 3 \\ \text { Weight } & =1.254 \mathrm{X} 0.913 \\ & =1.144 \mathrm{~g} \approx 1.2 \mathrm{~g} .\end{aligned}$

Weight of component with some loses = Actual Weight of component X Multiplication factor

$$
=1.2 \times 1.05=1.26 \mathrm{~g}
$$

- Clamping Force

Clamping Force $=\mathrm{Pa} \times(1 / 2$ to1/3) Pix N

Where,

$\mathrm{Pa}$ - Total projected area of the molding including the feed system.

$\mathrm{Pi}$ - Maximum injection pressure.

N- Number of cavities.

Projected area of the molding $=1997.05 \mathrm{~mm} 2=19.97 \mathrm{~cm} 2$

Feed system area $=30 \%$ (Projected area of the molding)

$$
=30 \%(19.97)=5.991 \mathrm{~cm} 2
$$

Therefore, $\mathrm{Pa}=19.97+5.991=25.96 \approx 26 \mathrm{~cm} 2$

Injection pressure for the material $(\mathrm{PP})=420$ to 1800

$\mathrm{Kg} / \mathrm{cm} 2$.

$1 / 2 \times 1100=555 \mathrm{Kg} / \mathrm{cm} 2$

$1 / 3 \times 1100=370 \mathrm{Kg} / \mathrm{cm} 2 \quad$ Average $=463 \mathrm{Kg} / \mathrm{cm} 2$

Number of cavities $\mathrm{N}=2$.

Therefore clamping force $=26 \times 463 \times 2=24$ tons
- Maximum Shot Weight

The shot weight of the mold must be lesser than the maximum shot weight

Maximum Shot weight $=\mathrm{Vs} \times \rho \times \mathrm{Cm}$

Where, Vs $=$ Swept Volume of cylinder in $\mathrm{cm} 3=153 \mathrm{~cm} 3$

$\rho=$ Density of the polymer at molding temperature $=0.96$ $\mathrm{g} / \mathrm{cm} 3$

Refer table literature survey

$\mathrm{Cm}=0.93$ is a constant, for amorphous material.

$\therefore$ Max Shot weight of the polymer $=153 \times 0.96 \times 0.93$ $=136.59 \mathrm{gms} \approx 137 \mathrm{gms}$

\section{Plasticizing rate \\ Plasticizing capacity -

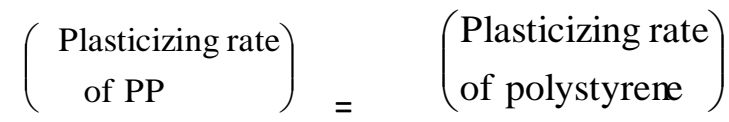 \\ $\left(\frac{\text { Total Heat content of PS }}{\text { Total Heat content of PP }}\right)$

Plasticizing rate of polystyrene (P.S) $=13.3 \mathrm{~g} / \mathrm{sec} \approx 0.013$ $\mathrm{kg} / \mathrm{sec}$.

Total Heat content of Polystyrene $=0.31 \mathrm{cal} / \mathrm{g}$

Total Heat of PP $=0.46 \mathrm{cal} / \mathrm{g}$

Plasticizing Rate of Material PP $=13.3$ X $(0.31 / 0.46)$

$$
\begin{gathered}
=8.963 \mathrm{~g} / \mathrm{sec} . \\
=32 \mathrm{~kg} / \mathrm{hr} .
\end{gathered}
$$

Cooling time $=\mathrm{Cc} \times$ (Max. Wall thickness) 2

Cc- Constant for $\mathrm{PP}=(1.9-4) \approx 3$.

Max wall thickness $=3 \mathrm{~mm}$.

Cooling time $=27 \mathrm{secs}$.

For $1 \mathrm{sec} 8.963$ grams of polymer is plasticized.

For 27 secs 242 grams of polymer is plasticized.

But the shot weight is 137 grams. Hence satisfied.

Clamping force-24 tons

Max shot weight of polymer-137 grams

Plasticizing rate- $32 \mathrm{~kg} / \mathrm{hr}$

Based on the above calculations,

Sp 80 machine is selected for production.

- Justification

The minimum clamping force required is 24 tons but the machine is capable of 80 tons clamping capacity. The maximum shot weight of the polymer is 137 grams and should be lesser than the maximum shot capacity of the machine which is 167 grams, hence satisfied.Calculated plasticizing rate is $32 \mathrm{~kg} / \mathrm{hr}$ which is lesser than the maximum plasticizing rate of the machine $48 \mathrm{~kg} / \mathrm{hr}$.

- Significance of Tie Bar Clearance

The dimensions of the mold/tool should be such that it should be possible to pass through the clearance between tie bars and it should be possible to accommodate the mold on platen of the machine.

For sp 80 machines

Horizontal clearance, $\mathrm{a}=$ $360 \mathrm{~mm}$. 
Vertical clearance, $b=395 \mathrm{~mm}$.

Width, $A=500 \mathrm{~mm}$.

Length, $B=490 \mathrm{~mm}$.

Tool dimensions are $(100 \mathrm{~mm} \times 70 \mathrm{~mm})$ less than $(360 \mathrm{~mm} \times$ $395 \mathrm{~mm})$.Hence, within the range.

- Significance of Maximum Daylight

Maximum daylight has to accommodate height of moving half of the mold, height of molded part, minimum and enough clearance for removal of molded part and height of fixed half of the mold.Maximum daylight of the mold/tool = $550 \mathrm{~mm}$.

For sp80 machine maximum daylight $=650 \mathrm{~mm}$.

Hence, within the range.

- Number of impressions

Calculation of the maximum number of cavities can be accomplished in three ways-

-maximum shot size

- clamping force.

$$
Q=\frac{\pi d 2}{4} . c \cdot \eta
$$

Where, $\mathrm{Q}=$ Maximum Shot Volume in Cubic Centimeters $\mathrm{d}=$ Screw Diameter in Centimeters $=42 \mathrm{~mm}($ For $\mathrm{Sp} 80)$

$\mathrm{c}=$ Screw Stroke in Centimeters $=135 \mathrm{~mm}($ For Sp 80)

$\mathrm{n}=$ Volumetric Yield (Approximately 0.85)

$\mathrm{Q}=159.04 \approx 160 \mathrm{~cm} 3$

Number of cavities Ns= (Maximum Shot Size) in cm3) / (Volume of the part and runner) in $\mathrm{cm} 3$.

$$
\begin{gathered}
=160 / 72 \\
\mathrm{Ns}=2.22 \approx 2 \text { numbers }
\end{gathered}
$$

Cycle Time, $\boldsymbol{T} \boldsymbol{c}=\boldsymbol{W} \boldsymbol{S} \cdot \frac{3600}{\boldsymbol{P}_{\boldsymbol{s} . \boldsymbol{K}}}$

$W s=$ Actual shot weight $=1.26$ grams .

$P S=$ Plasticizing rate $=32 \mathrm{~kg} / \mathrm{hr}$.

$K=$ Constant $=100$

Cycle time $\boldsymbol{T} \boldsymbol{C}=1.417 \approx 2$ seconds.

- Based On The Clamping Force

$$
\mathrm{NC}=\frac{c}{P c X P a} \text {. }
$$

Where, $\mathrm{C}=$ Clamping force $=80$ Tons

$\mathrm{PC}=$ Calculated average injection pressure $=463 \mathrm{Kg} / \mathrm{cm} 2$

$\mathrm{Pa}=$ total projected area of the molding $=26 \mathrm{~cm} 2$

$$
=80 \times 1000 /(463 \times 26)
$$

$\mathrm{NC}=6.64 \approx 7$ no's

From the above calculations, the minimum number of impression selected is two, as the machine used is $\mathrm{Sp} 80$ and increasing the number of impression may lead to increase in size of the mold which may eventually exceed the maximum daylight of the mold and the mold may not fit within the tie bars. Hence the tool is designed for two cavity.

- Solidifying Time (Ts)
$\mathrm{TS}=\frac{\rho \times \mathrm{a}}{\lambda_{\mathrm{p}}\left(\mathrm{t}_{\text {matl }}-\mathrm{t}_{\text {mold }}\right)} \times\left(\frac{\mathrm{t}^{2}}{8}\right)$

Where,

$\mathrm{TS}=$ Solidifying time $(\mathrm{sec})$

$\rho$ - Specific weight $=0.96 \mathrm{~g} / \mathrm{cm} 3$

$\mathrm{a}$ - Heat content of material $=0.46 \mathrm{cal} / \mathrm{g}$.

$\lambda \mathrm{p}$ - Thermal conductivity of $\mathrm{PP}=0.16^{\times 10^{-5}} \mathrm{cal} / \mathrm{cm}$. sec. ${ }^{\circ} \mathrm{C}$

$\mathrm{t}$ - Wall thickness of the molding $=0.2 \mathrm{~cm} \approx 2 \mathrm{~mm}$.

tmat- Injection temperature of material $=80^{\circ} \mathrm{C}$

tmold- Temperature of mold $=50^{\circ} \mathrm{C}$

$\mathrm{TS}=\frac{\rho \times \mathrm{a}}{\lambda_{\mathrm{p}}\left(\mathrm{t}_{\text {matl }}-\mathrm{t}_{\text {mold }}\right)} \times\left(\frac{\mathrm{t}^{2}}{8}\right)$

Where,

$\mathrm{TS}=$ Solidifying time $(\mathrm{sec})$

$\rho$ - Specific weight $=0.96 \mathrm{~g} / \mathrm{cm} 3$

$\mathrm{a}-$ Heat content of material $=0.46 \mathrm{cal} / \mathrm{g}$.

$\lambda \mathrm{p}$ - Thermal conductivity of $\mathrm{PP}=0.16^{\times 10^{-5}} \mathrm{cal} / \mathrm{cm}$. sec. ${ }^{\circ} \mathrm{C}$

$\mathrm{t}$ - Wall thickness of the molding $=0.2 \mathrm{~cm} \approx 2 \mathrm{~mm}$.

tmat- Injection temperature of material $=80^{\circ} \mathrm{C}$

tmold- Temperature of mold $=50^{\circ} \mathrm{C}$

On substituting the above values, we get

$\mathrm{TS}=\frac{0.96 \times 0.46}{0.16 \times 10^{-5}(80-50)} \times\left(\frac{0.2^{2}}{42}\right)=8$ seconds

Solidifying time, $\mathrm{TS}=8$ seconds

- Cycle Time $(\mathrm{Ct})$

Closing mold time + Fill time + Pack and Hold time + solidifying time + Open and ejection time.

$\mathrm{Ct}=4 \mathrm{sec}$ (say) $+1.67 \mathrm{sec}+6 \mathrm{sec}$ (say) $+8 \mathrm{sec}+4 \mathrm{sec}$ (say)

$=23.67 \mathrm{sec} \approx 24 \mathrm{sec}$.

Therefore no. of shots taken per hour $=3600 / 24$

$$
=150 \text { shots } / \text { hour }
$$

Weight of material injected $/$ shot $=1.26 \mathrm{~g}$.

- Heat Transferred Per Hour

$\mathrm{Q}=(\mathrm{m} \times \mathrm{a})$

Where,

$\mathrm{Q}=$ heat to be transferred per hour (cal/hr)

$\mathrm{m}=$ Mass of plastics material injected per hour $(\mathrm{g} / \mathrm{hr})$

$=1.25 \times 150=225 \mathrm{~g} / \mathrm{hr} \approx 0.225 \mathrm{~kg} / \mathrm{hr}$.

$\mathrm{a}=$ Heat content of the material $=0.46 \mathrm{cal} / \mathrm{g}$.

On substituting the above values, we have

$\mathrm{Q}=103.5 \mathrm{cal} / \mathrm{hr}$ 


\section{PROPOSED DESIGN}

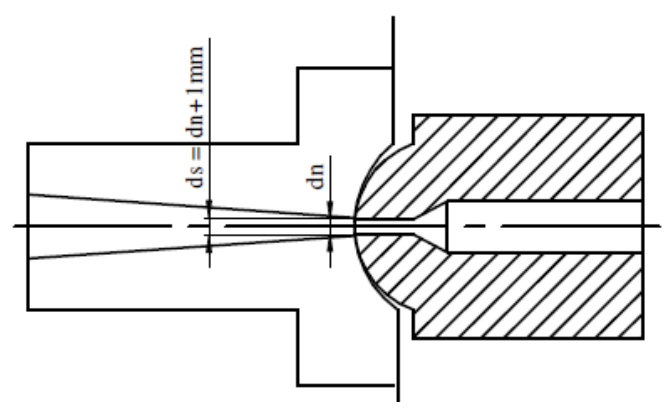

Fig. 3. Sprue Design

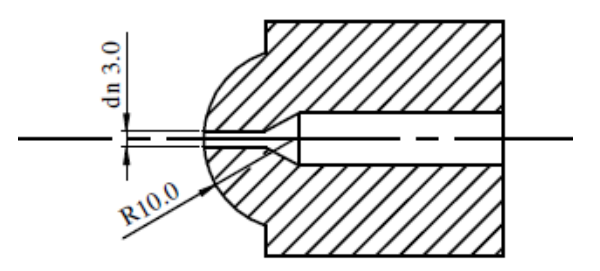

Fig. 4. Spherical radius

Figure 3 and figure 4 represents the Sprue design and Spherical radius.Nozzle Specifications for Sp80 Machine and Corresponding Sprue Design Nozzle specification for sp 80 machines dn Orifice diameter of the nozzle $=3 \mathrm{~mm}$. R Spherical radius of the nozzle tip $=10 \mathrm{~mm}$. The following general conditions determine the dimensions of the spherical contact surfaces and the orifice diameter of the sprue bushing $\mathrm{R}+1 \mathrm{~mm} \leq \mathrm{Rs}$

Rs - Spherical radius of the indentation in the sprue bushing $10 \mathrm{~mm}+1 \mathrm{~mm} \leq \mathrm{Rs}$

$11 \mathrm{~mm} \leq \mathrm{Rs}$

Hence, Rs $=11 \mathrm{~mm}$.

$\mathrm{ds} \geq \mathrm{dn}+1 \mathrm{~mm}$

ds -Orifice diameter of the sprue bushing

$\mathrm{ds}=3 \mathrm{~mm}+1 \mathrm{~mm}$.

$\mathrm{ds}=4 \mathrm{~mm}$.

\section{A. Design of the Sprue Gate}

The section thickness in the molding at gate location is around $2.5 \mathrm{~mm}$, but sprue gate must always be placed at the wide section and moreover the molding possess uneven wall thickness (greater than $2.5 \mathrm{~mm}$ ) hence in order to avoid sink marks and void and to maintain the holding pressure to compensate for the volume contraction during curing, the section thickness is increased in the form of a slug well thus serving multi-purpose i.e.,To maintain holding pressure and To take the cold material it is clear that variation in the part wall thickness leads to molded-in stresses which lead to variation in shrinkage and warpage problems. In order to avoid these problems, the thickness of the part at the gate location should be increased. Figure 5 and figure 6 shows the Sprue gate dimensions and slug well dimentions.

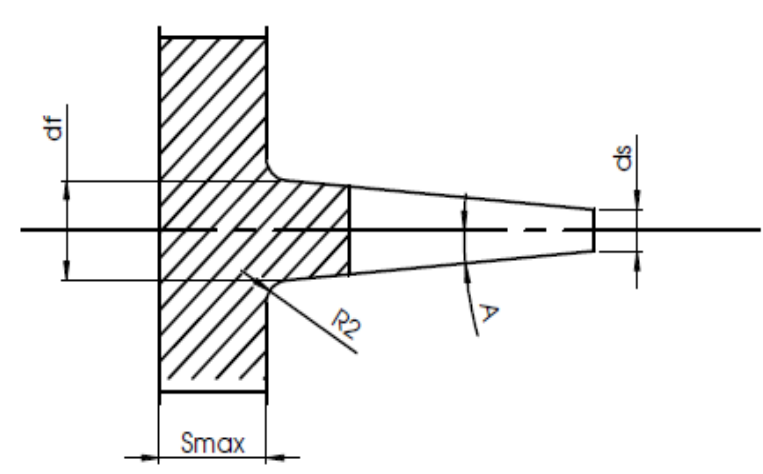

Fig. 5. Sprue Gate Dimensions

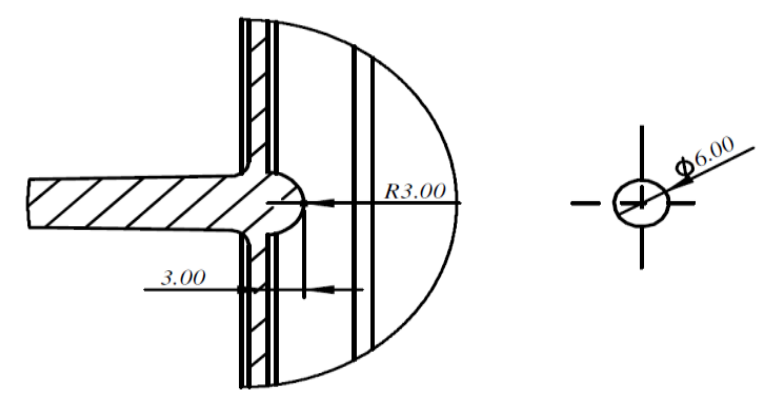

Fig. 6. Slug well dimensions

df - Sprue Diameter at the root.

R2 - Sprue Radius at the root.

A - Taper angle.

Smax - Maximum section thickness.

$\mathrm{df} \geq($ Smax $+1.5 \mathrm{~mm})=(2.5 \mathrm{~mm}+1 \mathrm{~mm})=3.5 \mathrm{~mm}$.

$\mathrm{R} 2=1$ to $2 \mathrm{~mm}$.

$\mathrm{A}=1$ to $2 \mathrm{deg}$

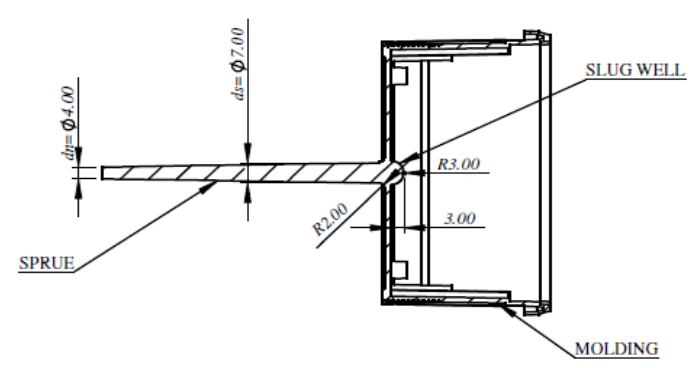

Fig. 7. Sprue gate

Figure 7 shows the Schematic Representation of The Feed System. Sprue gate design is selected

\section{B. Design of Core Insert}

This takes the inner profile of the component size of which depends on the size of the inner profile of the component (with added draft for ease in ejection) which is (10 X $49 \mathrm{X}$ 70). Since the design involves plate ejection and to accommodate for the cooling. 


\section{Design of Top Plate}

This plate houses the locating ring, sprue bush, support rods etc. with the clamping space of $20 \mathrm{~mm}$ either side the overall size of the plate is $(100 \times 70 \times 20) \mathrm{mm}$, this overall dimension of the plate is designed considering the distance between the tie bars to make it suitable for mounting the tool onto the machine.

\section{Design of Bottom Plate}

The size of the plate is same as that of the top plate, and this plate houses the rest pin holes, knock out rod holes etc. the overall size of the plate is $(100 \times 70$ X 20).

\section{E. Design of Core Plate}

This plate where core inserts, side cores are assembled so that it is in alignment with cavity inserts. It also provides provision for incorporating core back plate channel for arresting wear plates, the overall size of the plate is $(30 \times 70$ $\mathrm{X} 100)$.

\section{F. Manufacturing}

Some of the machining operations involved in the manufacturing of the tool are

- Pre-tooling

- Surface grinding

- Conventional machining

- Cnc machining

- Stage inspection

- Bench work

- Finishing

- Final inspection

Table- I: Comparison CAVITY INSERT MATERIAL: HDS

MATERIAL SIZE: (10 X 50 X 70)

\begin{tabular}{|c|c|c|c|c|}
\hline $\begin{array}{l}\text { OPER } \\
\text { ATION } \\
\text { NO }\end{array}$ & $\begin{array}{l}\text { DESCRI } \\
\text { PTION } \\
\end{array}$ & $\begin{array}{l}\text { MAC } \\
\text { HINE }\end{array}$ & $\begin{array}{l}\text { TOOLS/FI } \\
\text { XTURE }\end{array}$ & GAUGES \\
\hline 01 & $\begin{array}{l}\text { CUT } \\
\text { OFF } \\
\text { STOCK TO } \\
\text { SIZE (15) X } \\
55 \times 75)\end{array}$ & $\begin{array}{l}\text { SHA } \\
\text { PER } \\
\text { MACHI } \\
\text { NE }\end{array}$ & $\begin{array}{l}\text { CUTTING } \\
\text { TOOL }\end{array}$ & $\begin{array}{l}\text { SCALE,V } \\
\text { ERNIER }\end{array}$ \\
\hline 02 & $\begin{array}{l}\text { MIIIIN } \\
\text { TO TIZEF } \\
(10.5 \times 50.5 \\
\times 70.5)\end{array}$ & $\begin{array}{l}\text { MIILI } \\
\text { ING } \\
\text { MACHI } \\
\text { NE }\end{array}$ & $\begin{array}{l}\text { SHEII } \\
\text { ENDMILI } \\
\text { END } \\
\text { MILI }\end{array}$ & $\begin{array}{l}\text { VERNIER, } \\
\text { SCALE }\end{array}$ \\
\hline 03 & $\begin{array}{l}\text { GRINDI } \\
\text { NG AII } \\
\text { FACES TOO } \\
\text { SIZE (10.05 } \\
\text { X } 50.05 X \\
70.05)\end{array}$ & $\begin{array}{l}\text { GRIN } \\
\text { DING } \\
\text { MACHI } \\
\text { NE }\end{array}$ & WHEEL 202 & $\begin{array}{l}\text { VERIIER, } \\
\text { SCAIE }\end{array}$ \\
\hline 04 & $\begin{array}{l}\text { DRIIII } \\
\text { NG } \\
\text { CCOOLING } \\
\text { HOLES, } \\
\text { SCREW } \\
\text { HOLES, }\end{array}$ & $\begin{array}{l}\text { DRIL } \\
\text { LING } \\
\text { MACHI } \\
\text { NE }\end{array}$ & $\begin{array}{l}\text { DRILI } \\
\text { BITS }\end{array}$ & $\begin{array}{l}\text { VERNIER, } \\
\text { SCALE }\end{array}$ \\
\hline 05 & $\begin{array}{l}\text { GRINDI } \\
\text { NG } \\
\text { (FINSH } \\
\text { TOSIZE) }\end{array}$ & $\begin{array}{l}\text { GRIN } \\
\text { DING } \\
\text { MACHI } \\
\text { NE }\end{array}$ & WHEEL 202 & $\begin{array}{l}\text { MIICROM } \\
\text { ETER } \\
\text { VERNIER, } \\
\text { SCALE }\end{array}$ \\
\hline 06 & $\begin{array}{l}\text { INSPEC } \\
\text { TION } \\
\text { DDMENSI } \\
\text { ON } \\
\text { CHECKIN } \\
\text { G DONE } \\
\text { AS PEA PER } \\
\text { DRAWING }\end{array}$ & & & $\begin{array}{l}\text { VERNIER, } \\
\text { SCALE, } \\
\text { MOCROMET } \\
\text { ER }\end{array}$ \\
\hline
\end{tabular}

Fig. 8. Manufacturing details

Both core and cavity inserts follow almost the same procedure of manufacturing as follows stock size with $5 \mathrm{~mm}$ allowance is machined using shaper machine, later this stock is milled which involves roughing and finishing to size with $0.5 \mathrm{~mm}$ allowance, next the stock is grinded to the desired size (exact) as per the drawing, later the stock material is sent for bench work where all the required drilling holes are machined which includes Sprue hole screw holes, spring holes, cooling holes and channels etc. After the bench work it is passed to the $\mathrm{CNC}$ section.

\section{G. Assembly of the Tool}

Assembly is the stage in the manufacturing of the tool where the accurate alignment between the core and the cavity with respect to each other is done. The inserts are fitted in their respective housing (maintaining accurate pitches) which comprises of respective pockets or holes.

The plates are perfectly placed by maintaining similar pitches from the guiding elements, thus aligning the two halves. The parts were checked for required fit with their matching core in cavity, guide pillars in bushes, inserts in the plates, before final assembly. Opening and closing, component ejection system etc. are also checked. Process of checking for metal escape between the two halves of die when the metal is injected under high pressure is taken up. This involves coating one plate using tool maker blue.

\section{RESULT AND DISCUSSION}

Table- I: Inspection Report

\begin{tabular}{|c|c|c|c|c|c|}
\hline $\begin{array}{l}\text { SL. } \\
\text { NO }\end{array}$ & $\begin{array}{l}\text { Descri } \\
\text { ption }\end{array}$ & $\begin{array}{l}\text { Actual } \\
\text { dimens } \\
\text { ion }\end{array}$ & $\begin{array}{l}\text { Toler } \\
\text { ance }\end{array}$ & $\begin{array}{l}\text { Final } \\
\text { dim. }\end{array}$ & Gauges \\
\hline 1 & $\begin{array}{r}\text { Cor } \\
\text { eplate }\end{array}$ & $\begin{array}{ll}35 \mathrm{X} \\
75 & \mathrm{X} \\
105 & \end{array}$ & $1^{ \pm 0 .}$ & $\begin{array}{c}30 \times 7 \\
0.1 \times 100\end{array}$ & $\begin{array}{c}\text { SCALE, } \\
\text { VERNIER }\end{array}$ \\
\hline 2 & $\begin{array}{c}\text { Cor } \\
\text { e insert }\end{array}$ & $\begin{array}{r}15 \mathrm{X} \\
55 \mathrm{X} 75\end{array}$ & $1^{ \pm 0 .}$ & $\begin{array}{r}10 \times 4 \\
9.1 \times 70\end{array}$ & $\begin{array}{l}\text { VERNIE } \\
\text { R, SCALE, } \\
\text { MICROME } \\
\text { TER, }\end{array}$ \\
\hline 3 & $\begin{array}{l}\text { Cor } \\
\text { e pin }\end{array}$ & $\begin{array}{r}928 \\
\times 32\end{array}$ & $01^{ \pm 0}$ & $25^{\varnothing 20 \mathrm{x}}$ & $\begin{array}{l}\text { VERNIE } \\
\text { R, SCALE, } \\
\text { MICROME } \\
\text { TER, }\end{array}$ \\
\hline 4 & $\begin{array}{l}\quad \text { Cor } \\
\text { e back } \\
\text { plate }\end{array}$ & $\begin{array}{l}20 \mathrm{X} \\
75 \mathrm{X} 10 \\
5\end{array}$ & $1^{ \pm 0 .}$ & $\begin{array}{c}15 \times 7 \\
0.1 \times 100\end{array}$ & $\begin{array}{l}\text { VERNIE } \\
\text { R, SCALE }\end{array}$ \\
\hline 5 & $\begin{array}{l}\text { Top } \\
\text { plate }\end{array}$ & $\begin{array}{r}25 \mathrm{X} \\
75 \mathrm{X} 10 \\
5\end{array}$ & $1^{ \pm 0 .}$ & $\begin{array}{c}20 \times 7 \\
0.1 \times 100\end{array}$ & $\begin{array}{l}\text { VERNIE } \\
\text { R, SCALE }\end{array}$ \\
\hline
\end{tabular}

The possibility of defects in the molding is minimum. However problems such as sink marks, shrinkage, warpage, etc. which roots from the part design is observed in the component and is inevitable within the molding limits but the severity of the defects can be reduced within the molding limits which is achieved.

Manufacturing of the mould tool (2D, 3D and photos of tool) figure 10 and figure 11 shows the core insert and top/bottom plate. Figure 12 shows the core plate and closed condition of core plate is shown in the Figure 13. Figure 14 show the core insertion representation. 


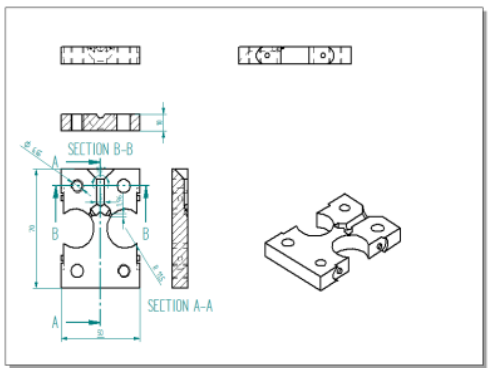

Fig. 9. Core insert

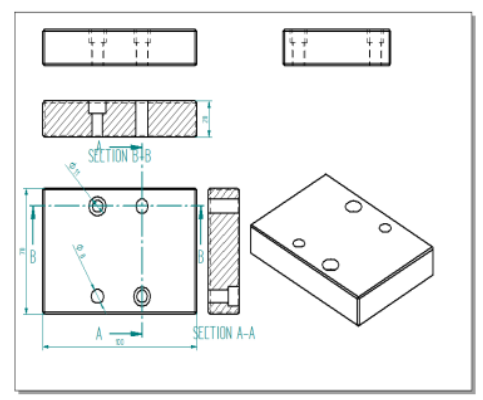

Fig. 10. Top/ bottom plate

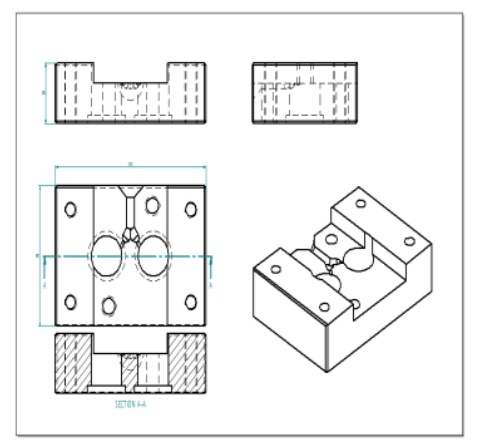

Fig. 11. Core plate

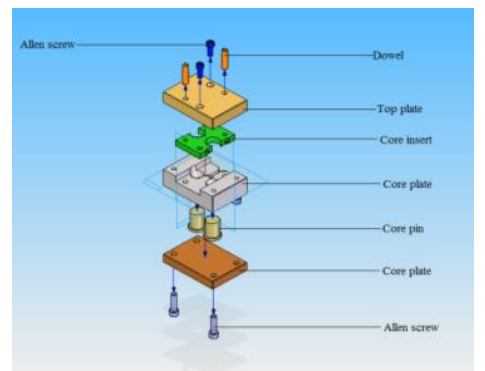

Fig. 12. Core plate

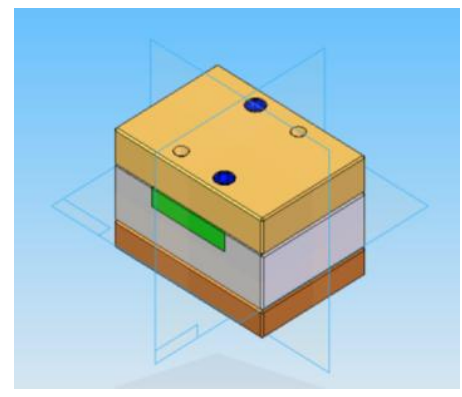

Fig. 13. Closed condition

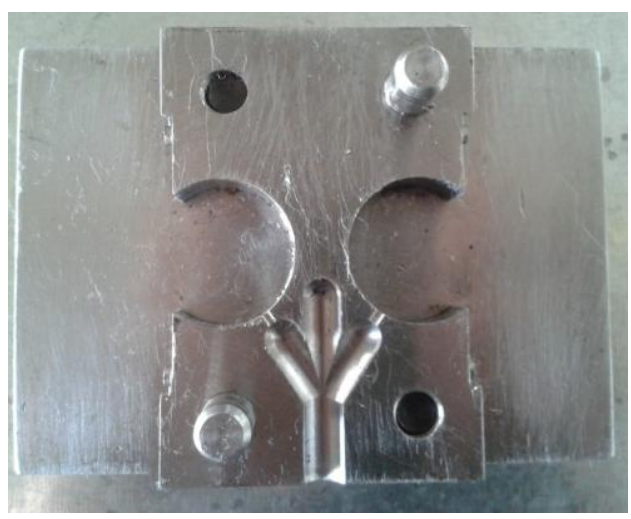

Fig. 14. Core insert

Figure 16 and figure 17 shows the core and cavity plate and assembly of the mould.

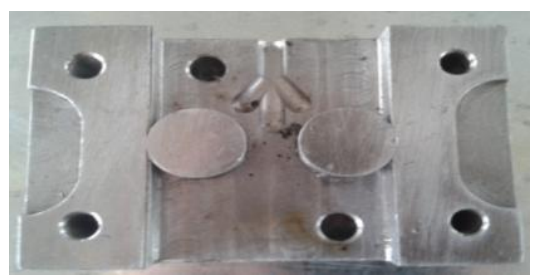

Fig. 15. Core and Cavity Plate

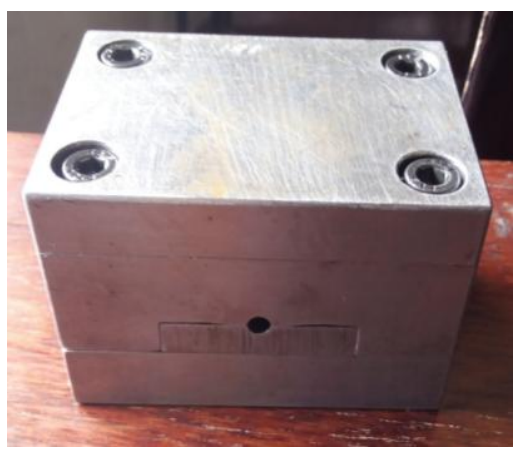

Fig. 16. Assembly of the mould

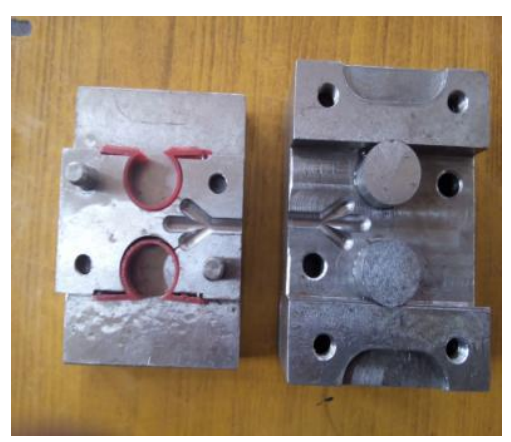

Fig. 17. After ejection of mould tool with component 


\section{CONCLUSION}

This report on "CABLE CLAMP" is carried out to give a clear picture of mould making and the machining processes involved in making a tool. However for certain limitation, lesser attempts have been made to include more theoretical aspects of mould design.

This project is an ideal references and refresher manual for normal procedure involved in tool making some of the problems involved in tryout are explained which can have its influence on trouble of other tools.

\section{REFERENCES}

1. A. L. Andrady ,M. A. Neal, "Applications and societal benefits of plastics", Philosophical Transactions of the Royal Society B: Biological Sciences, 364(1526), Jul.2009, pp.1977-1984.

2. S.S. Teklehaimanot, Simulation and Design of a plastic injection Mold,2012.

3. S. Nakamura, K. Yokoi, "Sankyo Engineering Co Ltd",Slide core mold and injection molding,Dec.1989.

4. Teklehaimanot, Samson Seged. "Simulation and Design of a plastic injection Mold",2007.

5. B. Murti," Simulation and Analysis of Injection Moulding product and rapid prototyping", Lisans Tezi, Arcada University of Applied Science Industrial Management, Helsinki, 74s,2010.

6. T. Huff, J.J. McAlpin, "ExxonMobil Chemical Patents Inc", Thermoplastic polymer compositions and their production and use. U.S. Patent 5,747,592,May.1998.

7. R. J. Crawford, “Plastics engineering”, Elsevier,Feb.1998.

8. Z.H.A.N.G, Hongrong, W. Yunfang, "The Properties of High-Performance Semi-Aromatic Nylon Engineering Plastics and Progress in Application", Fine Chemical Intermediates, 2002.

9. D. Rosato, D. Donald,D. Marlene, "Injection molding handbook. 3rd ed.Norwell massachusetts 02061: Kluwer Academic Publishers, 2000.

10. M. N. Subramanian, ). John Wiley \& Sons, "Basics of troubleshooting in plastics processing”, an introductory practical guide (Vol. 51), Apr.2011.

11. D. Papageorgiou, C. Medrea, N. Kyriakou, N., 2013. "Failure analysis of H13 working die used in plastic injection moulding.", Engineering failure analysis, 35, pp.355-359,Dec.2013.

12. C. S. Tse, J. H. Neely, Semantic and repetition priming effects for Deese/Roediger-McDermott (DRM) critical items and associates produced by DRM and unrelated study lists. Memory \& Cognition, 35(5), jul.2007, pp.1047-1066.

13. J. H. Choi, S. H. Choi, S.H, D. Park, C. H. Park, B. O. Rhee, D. H. Choi, "Design optimization of an injection mold for minimizing temperature deviation. International Journal of Automotive Technology, 13(2), Feb.2012, pp.273-277.

14. P. E. Cassidy, T. M. Aminabhavi, C. M. Thompson, "Water permeation through elastomers and plastics",Rubber chemistry and technology, 56(3), Jul.1983, pp.594-618.

\section{AUTHORS PROFILE}

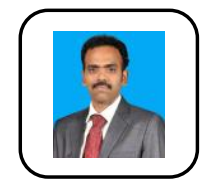

J Senthil*, Assoc. Prof., Department of Mechanical Engineering , Aarupadai Veedu Institute of Technology, Vinayaka Mission's Research Foundation, Deemed to be University. Having 13 years of experience. Life member in ISTE and MMS.

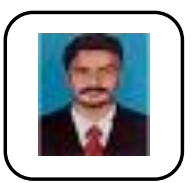

M.Saravanan, Assistant Professor, Mechanical Department, Aarupadai Veedu of Technology, Vinayaka Mission's Research Foundation, Deemed to be University. Having 8 years of experience. Life member in ISTE.

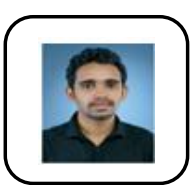

Alby Berchmans, UG Student, Department of Mechanical Engineering , Aarupadai Veedu Institute of Technology, Vinayaka Mission's Research Foundation, Deemed to be University.

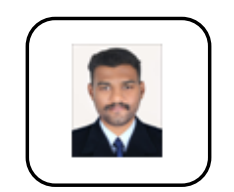

Bipin Wilson, UG Student, Department of Mechanical Engineering , Aarupadai Veedu Institute of Technology, Vinayaka Mission's Research Foundation, Deemed to be University.

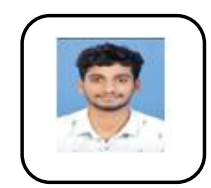

Christin Varghese, UG Student, Department of Mechanical Engineering, Aarupadai Veedu Institute of Technology, Vinayaka Mission's Research Foundation, Deemed to be University . 